\title{
The synergistic action of Azospirillum brasilense and effective microorganisms promotes growth and increases the productivity of green corn
}

Ação sinergística do Azospirillum brasilense e micro-organismos eficazes promove o crescimento e aumenta a produtividade do milho verde

\author{
F. V. da Silva ${ }^{1}$; R. R. G. F. Costa ${ }^{1}$; L. C. Vitorino ${ }^{2 *}$; L. S. Porto ${ }^{1}$; S. C. Santos ${ }^{1}$; T. \\ S. Santos ${ }^{1}$; A. F. de S. Rocha ${ }^{2}$ \\ ${ }^{1}$ Universidade Estadual de Goiás (UEG), Campus Sudoeste (Quirinópolis), 75860-000, Quirinópolis-GO, Brazil \\ ${ }^{2}$ Laboratory of Agricultural Microbiology, Instituto Federal Goiano, Campus Rio Verde, 75901-970, Rio Verde-GO, \\ Brazil
}

*luciana.vitorino@ifgoiano.edu.br

(Recebido em 26 de outubro de 2020; aceito em 22 de abril de 2021)

\begin{abstract}
In view of the current dissemination of even more sustainable techniques, which allow the producer to explore the microbial biodiversity native to the property's soil and obtain effective microorganisms (EM), the hypothesis was tested that the biopriming of corn seeds using the co-inoculation of A. brasilense + EM could promote growth and increase the productivity of green corn. Additionally, the effect of treating seeds with humic acids was evaluated. For this, a field experiment was conducted using the following treatments: $A$. brasilense; EM; A. brasilense + EM; humic acids (Solo Humics) and Control. Co-inoculation of A. brasilense + EM potentiated the growth-promoting effects of diazotrophic (height and stem diameter increased 30 days after sowing - DAS, fresh and dry mass of aerial part at 90 DAS and dry mass of root at 60 and 90 DAS) and increased productivity of green corn (presented the highest averages for ear weight with and without straw). The treatment of seeds with humic acids showed promising effects only in the initial stages of crop development - when the plants evaluated were at 30 DAS. However, in the final evaluation phase (90 DAS) the effect of these acids became less satisfactory than microbial inoculation. The enrichment of inoculants of A. brasilense with EM is therefore a viable alternative for promoting growth and increasing productivity in the cultivation of green maize in addition to being a low complexity technology and even cheaper than the simple use of commercial inoculants.
\end{abstract}

Keywords: rhizobacteria, commercial inoculants, Zea mays L.

Tendo em vista a atual disseminação de técnicas ainda mais sustentáveis, que permitem ao produtor explorar a biodiversidade microbiana nativa do solo da propriedade e obter microorganismos eficazes (EM), testouse a hipótese de que o biocondicionamento de sementes de milho por meio do coinoculação de A. brasilense + EM pode promover o crescimento e aumentar a produtividade do milho verde. Além disso, foi avaliado o efeito do tratamento das sementes com ácidos húmicos. Para isso, foi conduzido um experimento em campo, utilizando os seguintes tratamentos: A. brasilense; EM; A. brasilense + EM; ácidos húmicos (Solo Humics) e Controle. A coinoculação de A. brasilense + EM potencializou os efeitos promotores de crescimento de diazotróficos (altura e diâmetro do caule aumentaram 30 dias após a semeadura - DAS, massa fresca e seca da parte aérea aos 90 DAS e massa seca da raiz aos 60 e 90 DAS ) e aumento da produtividade do milho verde (apresentou as maiores médias para peso da espiga com e sem palha). $\mathrm{O}$ tratamento das sementes com ácidos húmicos apresentou efeitos promissores apenas nos estágios iniciais de desenvolvimento das plantas, ou seja, nas plantas avaliadas aos 30 DAS, entretanto, na fase final de avaliação (90 DAS) o efeito desses ácidos tornou-se menos satisfatório do que a inoculação microbiana. $\mathrm{O}$ enriquecimento de inoculantes de $A$. brasilense com EM é, portanto, uma alternativa viável para promover o crescimento e aumentar a produtividade no cultivo do milho verde, além de ser uma tecnologia de baixa complexidade e ainda mais barata que o simples uso de inoculantes comerciais.

Palavras-chave: rizobacteria, inoculantes comerciais, Zea mays L. 


\section{INTRODUCTION}

One of the biggest challenges of modern agriculture is balancing the growing demand for food with the rational use and occupation of the environment. In this context, the development and application of technologies that guarantee productivity and that do not generate negative environmental effects have been stimulated. Researchers that prospect new microbial strains that use functional traits of microorganisms to control phytopathogens or promote plant growth have become very common [1, 2, 3], aiming at alternatives to pesticide and fertilizer use in crops [4].

The first microbial inoculant for plants was developed about 100 years ago. However, in recent decades, farmer receptivity of these products has considerably improved due to the expressive improvements in crop productivity [5]. The main inoculants currently found on the market consist of unique microbial strains, with proven efficiency. Despite this, in the last decade, mixed inoculants have conquered the market. Co-inoculations are intended to associate different functional traits, often expressed by different microorganisms $[6,7,8]$. In this way, biological nitrogen fixation (BNF), phytohormone synthesis, the ability of antibiosis to pathogens, as well as solubilization of different nutrients can be achieved with the use of the same inoculant, formulated from the mixture of two or more strains.

The use of commercial inoculants contributes considerably to cost reduction of chemical fertilization in different cultures, inexpensive and low complexity techniques, which allows for obtaining efficient microbial formulations from the native microbial biodiversity of the property's soil, and decreasing the general expenses with planting. These techniques use effective microorganisms (EM). EM are consortia of microorganisms that, when used as inoculants, increase the microbial diversity of the soil [9], absorption of $\mathrm{P}$ and $\mathrm{Zn}$ [10], favors photosynthetic processes [11], assist in the decomposition of organic matter [12], have an antagonistic effect to soil pathogens [13], anticipate seed germination [14], and contribute to increased grain productivity [8, 15, 16]. These microorganisms are easy to obtain and are mainly recommended for use in family farming.

Therefore, taking into account the positive effects of the use of inoculants based on Azospirillum brasilense, in a single lineage, for the corn culture [17, 18, 19] and taking into account the lack of tests that associate this diazotrophic to EM in this culture, we decided to test the hypothesis that the biopriming of corn seeds using the co-inoculation of A. brasilense + EM could promote growth and increase the productivity of green corn. Additionally, we also tested the treatment of seeds with humic acids. Humic acids stimulate the production of plant hormones, especially auxin, resulting in the growth and development of roots [20,21, 22, 23]. These acids also altered soil chemistry and microbial dynamics in the rhizosphere [24], influencing soil-microorganism-plant interactions, mainly on nutrient availability and assimilation [22]. Given the above, the objective of this work was to evaluate the effect of biopriming of corn seeds with EM and A. brasilense isolated and in co-inoculation as well as the effect of the treatment of seeds with humic acids on the growth and productivity of green maize.

\section{MATERIAL AND METHODS}

\subsection{Experiment Location}

The experiment was carried out at Fazendinha farm in Quirinópolis - GO, Brazil (18 24'45.32" S, 50 $23^{\prime} 51.34^{\prime \prime} \mathrm{W}$ ), at an average altitude of 544 meters, in a dystroferric Red Latosol [25]. Before the implementation of the experiment, the experimental area had been cultivated in the São Francisco Agriculture-Livestock Integration (ILP) system, using corn and mombasa grass (Megathyrsus maximum), providing good straw availability after desiccation (Figure 1a). 


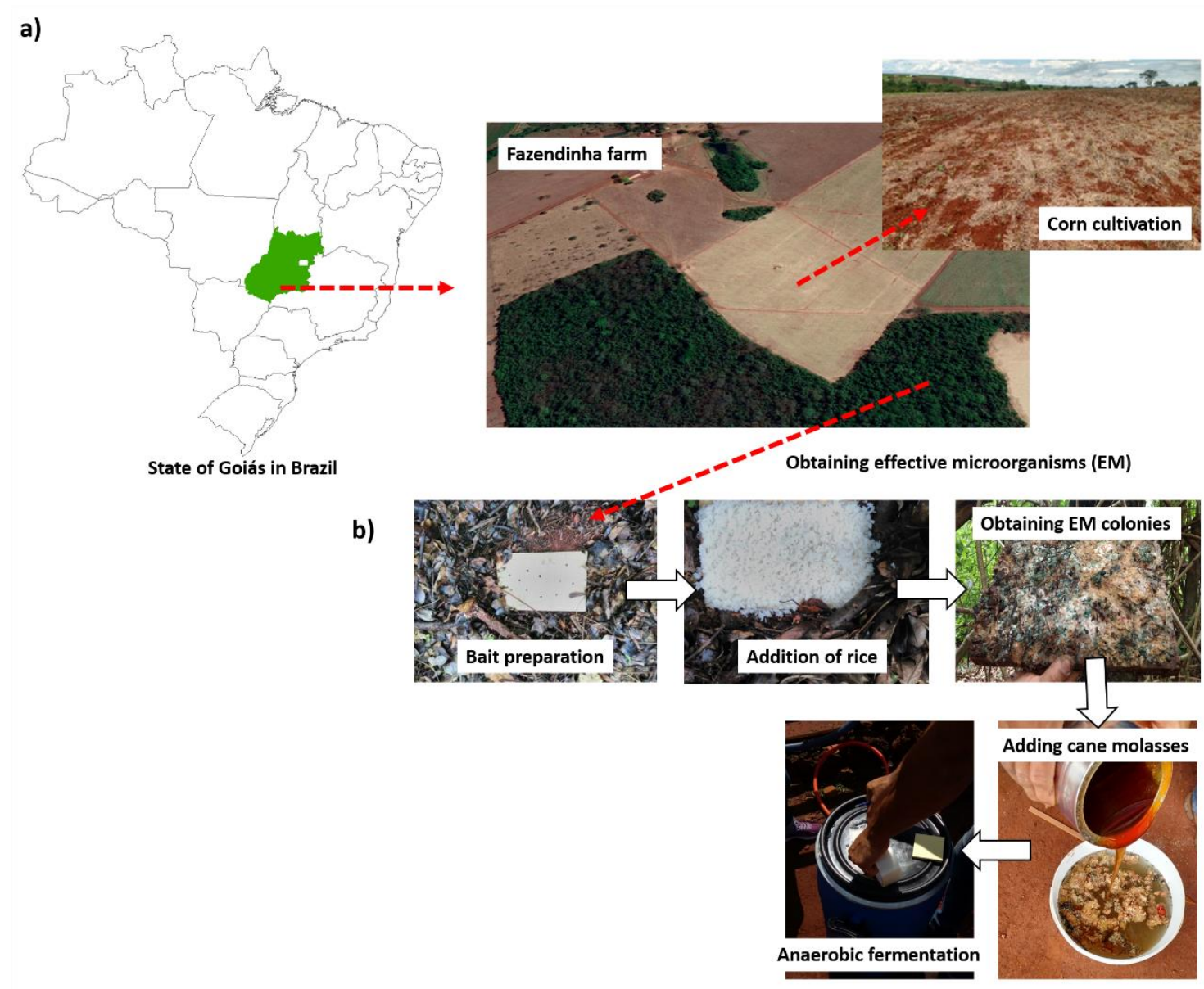

Figure 1: Location of the Fazendinha farm in the municipality of Quirinópolis, Goiás, Brazil and place of implementation of the experiment in an area of corn cultivation (a). Preparation of baits to obtain effective microorganisms (EM) in the forest reserve area of Fazendinha farm and preparation of the inoculant $(b)$.

The chemical and physical characteristics of the soil in the $0-20 \mathrm{~cm}$ layer were determined. The soil was characterized as follows: 270 texture; $80 ; 650 \mathrm{~g} \mathrm{~kg}^{-1}$ of clay, silt and sand, respectively; pH in CaCl2: 4.83; Ca: 1.14 cmolc dm-3; $\mathrm{Mg}: 0.33 \mathrm{cmolc} \mathrm{dm}^{-3}$; $\mathrm{Al}: 0.05 \mathrm{cmolc} \mathrm{dm}^{-3} ; \mathrm{Al}+\mathrm{H}: 4.46$ cmolc dm${ }^{-3}$; K: $0.36 \mathrm{cmolc} \mathrm{dm}^{-3}$; CTC: $6.33 \mathrm{cmolc} \mathrm{dm}^{-3} ; \mathrm{P}: 7.29 \mathrm{mg} \mathrm{dm}^{-3} ; \mathrm{Cu}: 2.22 \mathrm{mg} \mathrm{dm}^{-3}$; Zn: $0.90 \mathrm{mg} \mathrm{dm}^{-3}$; Fe: $23.53, \mathrm{mg} \mathrm{dm}^{-3}$; Mn $38.00 \mathrm{mg} \mathrm{dm}^{-3}$ and M.O.: $34.00 \mathrm{dm}^{-3}$. It was applied 4.51 ha $^{-1}$ of herbicide glyphosate $\mathrm{N}$ - (phosphonomethyl) glycine, concentration: glyphosate ammonium salt $792.5 \mathrm{~g} / \mathrm{kg}(720 \mathrm{~g} / \mathrm{kg}$ acid equivalent $)$, and syrup volume of $1501 \mathrm{ha}^{-1}$, for desiccation of mombasa grass, remaining of the São Francisco ILP system. Liming was done using 1.2 tons ha ${ }^{-1}$ of calcitic limestone with 75 percent RTNP (Relative total neutrality power).

\subsection{EM preparation}

EM were attracted to "baits", using rice as organic matter. These baits were prepared by cooking approximately 700 grams of unsalted rice, which was placed on $15 \times 20 \mathrm{~cm}$ wooden boards. Five boards were installed on exposed soil, after the total removal of the litter, according to the methodology of Porto et al. (2020) [15]. After installation, a layer of litter was added as a cover (Figure $1 \mathrm{~b}$ ) and the apparatus was covered with a fine TNT canvas that were placed on wooden supports in order to protect against raindrops. The installation took place in a legal reserve Semidecidual Seasonal Forests, also located in the Fazendinha farm area $\left(18^{\circ} 24^{\prime} 22^{\prime \prime}\right.$ S, 50 $23^{\circ} 34^{\prime \prime}$ $\mathrm{W}$ at $544 \mathrm{~m}$ elevation) (Figure 1a). The colonization of the baits by the local microbiota was monitored daily, from the 11th day of incubation, and total colonization was observed on the 15th 
day when the boards were removed and taken to the Microbiology Laboratory of the Goiás State University, Sudoeste campus, for isolation of EM.

The colonies were selected from the baits following the methodology proposed by Bonfim et al. (2011) [26], with only those containing pink, blue, yellow, and orange colors maintained.

To activate the EM, the selected colonies were added to five liters of cane molasses diluted in 50 liters of clean water (without chlorine). Thus, the EM production process was carried out in nonsterile conditions. The mixture was placed in a 70-liter plastic drum, the container being hermetically closed and left to rest in the shade for 25 days. To reduce the pressure of the fermentation process (anaerobic), the drum was opened every two days. At 25 days, the fermentation process ceased and the inoculant showed the expected characteristics, which were orange in color and a pleasant sweet odor. The number of colony forming unit (CFUs) per mL of the inoculant was quantified using the serial dilution technique [27].

\subsection{Seed treatment and sowing}

Seeds of simple hybrid corn MG 711 from Morgan Sementes ${ }^{\circledR}$ were subjected to biopriming using the inocula of interest (EM and Azospirillum brasilense) and treated with humic acids (Solo Humics). The EM were applied at a concentration of $3.4 \times 10^{5} \mathrm{CFU} \mathrm{mL}{ }^{-1}$, under the dose of $20 \mathrm{~mL}$ $5 \mathrm{~kg}^{-1}$ of seeds. The inoculation of Azospirillum brasilense was performed using commercial inoculant of the strains AbV5 and AbV6, brand AzoTotal ${ }^{\circledR}$ of the company Total Biotecnologia Indústria e Comércio Ltda, registered with MAPA under the number PR-93923 10074-1. The

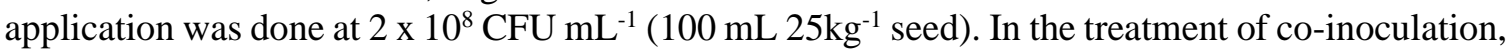

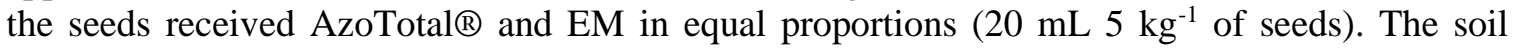
conditioner used was the humic acid of the brand SoloHumics ${ }^{\circledR}$ (mixture of humic and fulvic acids in $\mathrm{H}_{2} \mathrm{O}$, peat and $\mathrm{KOH}$ ) registered in MAPA number-BA-32601-1, being applied in the dose of 50 $\mathrm{mL} 5 \mathrm{~kg}^{-1}$ of seeds. Seed treatment was carried out with the aid of transparent plastic bags and a 50$\mathrm{mL}$ syringe. The treated seeds were mixed and dried in the shade for 20 minutes before sowing.

The experiment was designed in randomized blocks, with five treatments: biopriming with $A$. brasilense; biopriming with EM; biopriming with A. brasilense + EM; treatment with humic acids (Solo Humics) and without biopriming or untreated seeds (Control). The experimental plots consisted of seven six-meter lines, with 0.50 -meter spacing between lines, with four repetitions. Sowing was carried out aiming to reach a population of 65,000 plants $\mathrm{ha}^{-1}$ considering the variety of corn used.

The seeds were planted on Nov. 26, 2019, with the aid of a seven-row mechanized planter, with three $\mathrm{cm}$ deep grooves. At the time of sowing, chemical fertilization was carried out with $400 \mathrm{~kg}$ $\mathrm{ha}^{-1}$ in formulation 8-20-20, being the sources $\left(\mathrm{N}, \mathrm{P}_{2} \mathrm{O}_{5}\right.$ and $\left.\mathrm{K}_{2} \mathrm{O}\right)$, respectively nitrogen, triple superphosphate and potassium chloride. At 60 days after sowing (DAS), foliar fertilization was applied using the commercial product Nitamin ${ }^{\circledR}\left(33\right.$ percent N) $4 \mathrm{~L} \mathrm{ha}^{-1}$.

As post-emergent, two liters of the herbicide glyphosate $\mathrm{N}$ - (phosphonomethyl) glycine was

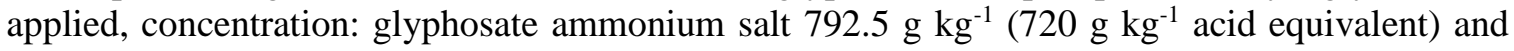
two liters of Atrasine Nortox $5 \mathrm{OO}$ SC (-6-chloro-N2-ethyll-N4-isopropyl-1,3,5-triazine-2,4diamine (ATRAZINE), at $500 \mathrm{~g} \mathrm{~L}^{-1}(50$ percent $\mathrm{w} / \mathrm{v}$ ) per hectare. For carcass caterpillar (Spodoptera frugiperda) control, were applied LORSBAN $480 \mathrm{BR}$ (chlorpyrifos), (480 $\left.\mathrm{g} \mathrm{L}^{-1}\right) 1 \mathrm{~L} \mathrm{ha}^{-1}$ and for fungi control Abacus HC was used, equivalent to 260 grams of Pyraclostrobin and 160 grams of Epoxiconazole $\left(300 \mathrm{ml} \mathrm{ha}^{-1}\right)$.

Data were collected at 30, 60, and 90 (DAS) (December 2019 to February 2020). At 30 DAS, the following response variables were evaluated: plant height $(\mathrm{m})$ and stem diameter $(\mathrm{cm})$; at 60 and 90 DAS: plant height $(\mathrm{m})$, stem diameter $(\mathrm{cm})$, fresh and dry mass of the aerial part $(\mathrm{g})$, and fresh and dry mass of the roots (g). At 90 DAS, the productivity characteristics of green corn were also evaluated. For this, the ears were harvested and evaluated for the average weight of commercial ears with and without straw (g) as well as average length and diameter of commercial ears without straw. Commercial ears were considered to be longer than $15 \mathrm{~cm}$, as Moreira et al. (2010) [28] and with an average diameter greater than four $\mathrm{cm}$, grenades and free from injuries caused by insect pests and diseases. 
The data was obtained with the aid of a tape measure, manual caliper, and precision scale, being collected from 15 plants, obtained from the four central lines of the useful area of the $15 \mathrm{~m}^{2}$ plot. To determine the dry mass of the aerial part, the plants were cut close to the soil. The roots were extracted from the soil with the aid of a hoe, and a radius of $30 \mathrm{~cm}$ of soil was removed around the roots. These were later washed to remove the adhered soil. The plant material was dried in an oven with forced aeration at $55^{\circ} \mathrm{C}$ until it reached constant mass.

The data was submitted to analysis of variance (ANOVA) and when they were proven significant by the $\mathrm{F}$ test, the averages were compared by the Tukey test at five percent probability. Statistical analyses were conducted using RStudio 1.2.1335 [29].

\section{RESULTS}

The biopriming of corn seeds with A. brasilense + EM positively affected the plant height only at $30 \mathrm{DAS}$, so that the plants submitted to this treatment had the highest average for this variable $(0.64 \mathrm{~m})$. This average was significantly higher than that observed for the Control $(0.57 \mathrm{~m})$ (difference between means $=7.00, p=0.005)$ and also for plants submitted to EM only $(0.58 \mathrm{~m})$ (difference between means $=5.55, p=0.010$ ) (Figure 2a, c and e). At 30 DAS, the treatment of seeds with Solo Humics also positively affected growth, with the average height $(0.62 \mathrm{~m})$ being significantly different from that observed for the Control (difference between means $=5.27, p=$ $0.018)$.
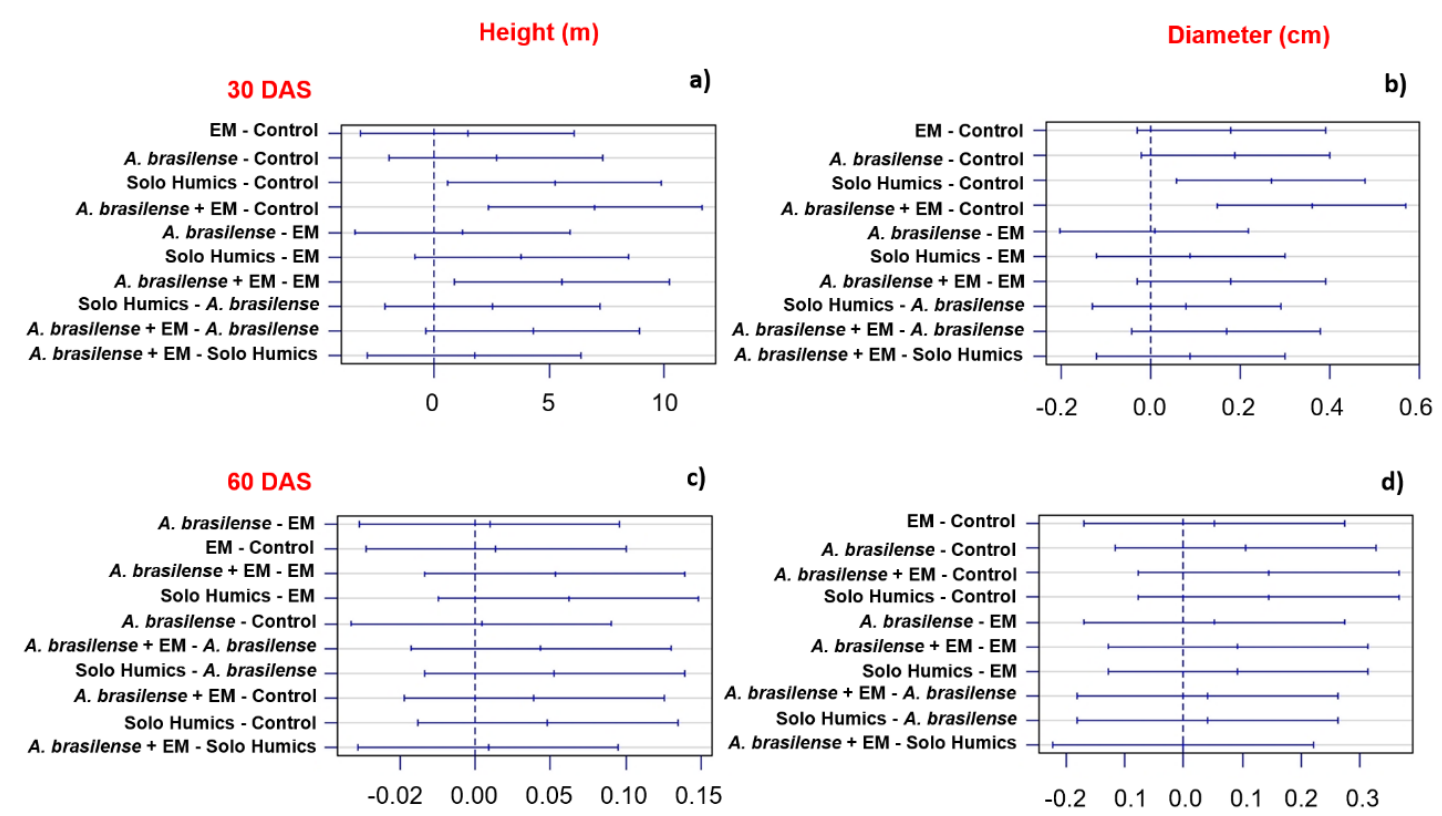

90 DAS

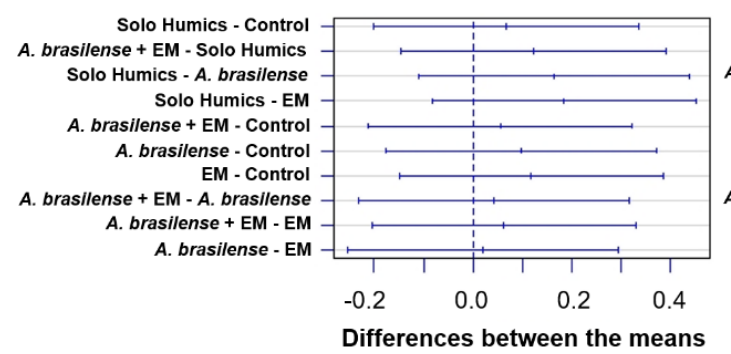

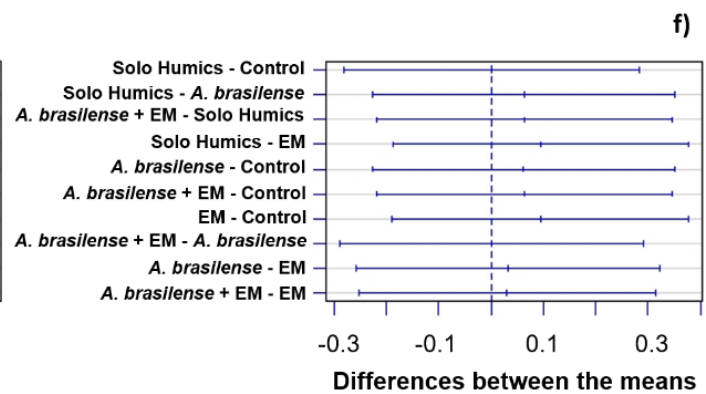

Figure 2: Differences between the mean of the Height $(\mathrm{m})$ and Diameter $(\mathrm{cm})$ observed at $30(a$ and $b), 60$ $(c$ and $d)$ and 90 days ( $e$ and f) after sowing (DAS) for corn plants submitted to treatment with effective microorganisms (EM), A. brasilense, A. brasilense + EM, humic acids (Solo Humics) and Control. The y axis shows the treatments being compared. The vertical bars represent the $95 \%$ Confidence Interval of the differences. 
Similar behavior was observed when comparing the averages obtained for stem diameter. At 30 DAS, the average diameter of the plants submitted to A. brasilense + EM $(2.22 \mathrm{~cm})$ was higher than that observed for the Control $(1.86 \mathrm{~cm}$ ) (Difference between means $=0.36, p<0.001)$. During this period, plants treated with Solo Humics also effectively developed their diameter $(2.13 \mathrm{~cm})$ in relation to Control plants (difference between means $=0.27, p=0.004$ ) (Figure 2b).

At 60 and 90 DAS, the different treatments did not affect the height or the diameter of the plants (Figure $2 \mathrm{~d}$ and $\mathrm{f}$ ), however, when evaluating the total growth through fresh and dry mass, different responses were observed. At $60 \mathrm{DAS}$, the biopriming of corn seeds with A. brasilense + EM promoted the worst result in terms of fresh mass of the aerial part (654.03 g) (Figure 3a). However, at 90 DAS, this treatment, as well as the treatment using only A. brasilense as inoculum, led to a greater accumulation of fresh matter in the aerial part, at 584.53 grams and 589.98 grams, respectively (Figure 3c).

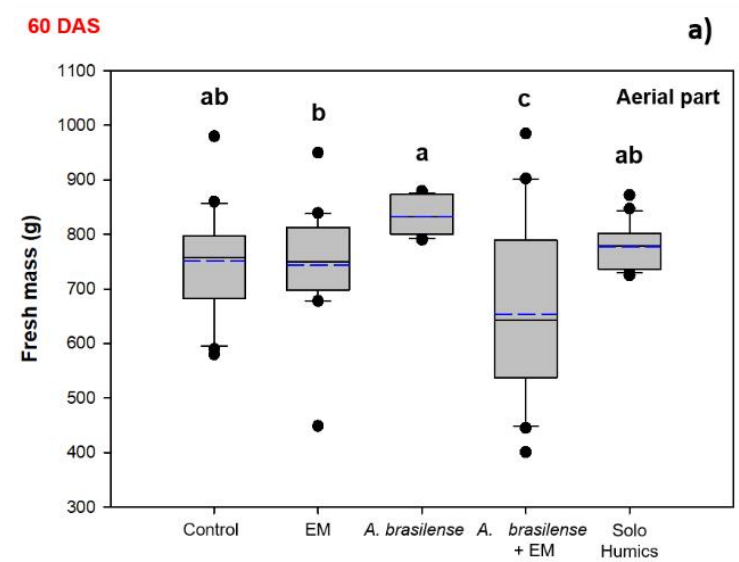

b)
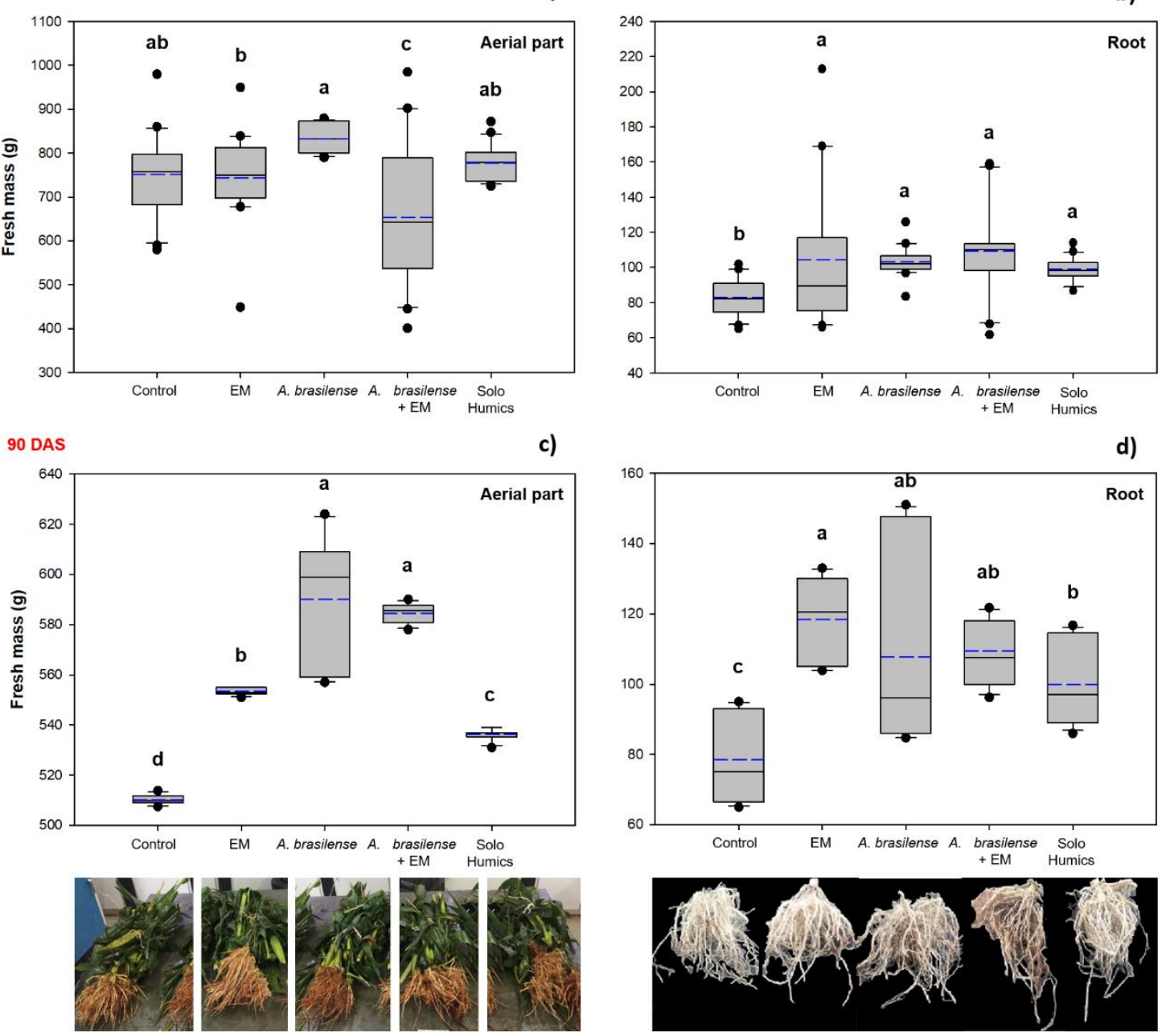

Figure 3: Fresh mass $(g)$ observed at $60(a$ and $b)$ and 90 days ( $c$ and $d)$ after sowing (DAS) for the aerial part and root of corn plants submitted to treatment with effective microorganisms (EM), A. brasilense, A. brasilense + EM, humic acids (Solo Humics) and Control. In the boxplot, the black line represents the median, the blue line the average and points observed outside are outliers. Above the boxplots, means followed by the same letter do not differ significantly by Tukey's test at 5\% probability.

At 60 DAS, the fresh root mass was positively affected by all inoculation treatments, with the worst averages observed in the plants of the Control treatment (82.94 g) (Figure 3b), but at 90 DAS, the plants subjected to EM, A. brasilense + EM and A. brasilense, had the highest averages observed for this variable (118.44 grams, 109.43 grams, and 107.72 grams, respectively) (Figure 3d). In this 
period, the plants of the Control treatment showed the worst averages observed for fresh root weight (78.41 grams).

In relation to the dry mass of the aerial part, at $60 \mathrm{DAS}$, the inoculation treatments were not more efficient than the Control in promoting accumulation, with the highest averages observed in the plants treated with $A$. brasilense (238.87 grams), similar to those observed in the Control plants (218.98 grams) (Figure 4a). However, at 90 DAS, the plants submitted to A. brasilense + EM were significantly superior to the others in accumulating dry mass in the aerial part (123.4 grams) (Figure $4 c)$.
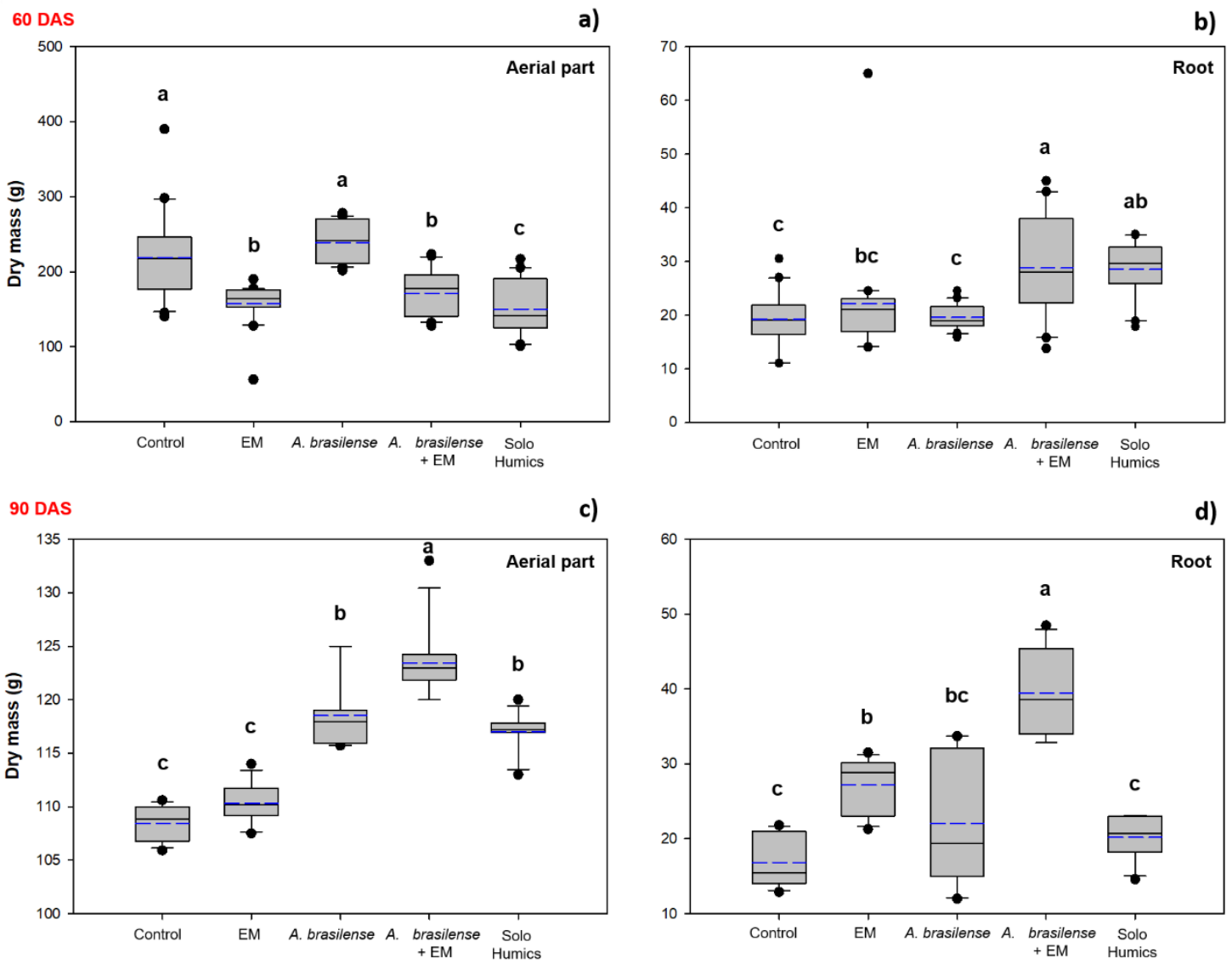

c)

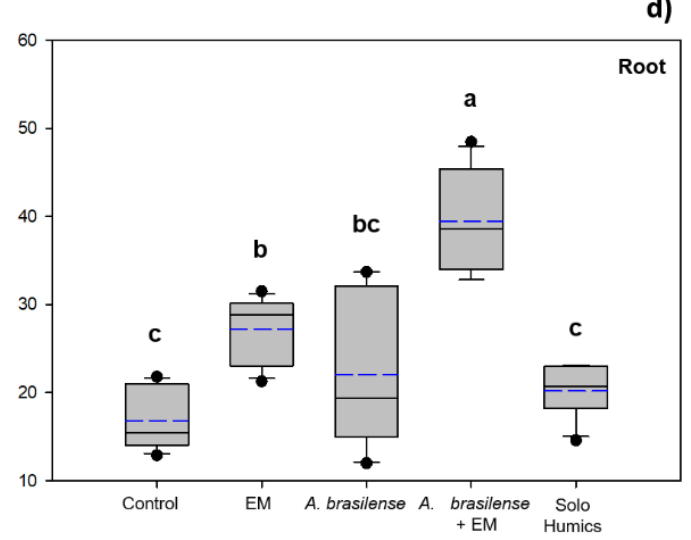

Figure 4: Dry mass ( $g$ ) observed at $60(a$ and $b)$ and 90 days ( $c$ and d) after sowing (DAS) for the aerial part and root of corn plants submitted to treatment with effective microorganisms (EM), A. brasilense, A. brasilense + EM, humic acids (Solo Humics) and Control. In the boxplot, the black line represents the median, the blue line the average and points observed outside are outliers. Above the boxplots, means followed by the same letter do not differ significantly by Tukey's test at 5\% probability.

The highest averages for dry root weight were observed in plants submitted to A. brasilense + EM (28.70 grams) and in those treated with Solo humics (28.48 grams), at 60 DAS (Figure 4b). However, at 90 DAS, the plants treated with Solo humics dropped their accumulation (20.19 grams) and the plants subjected to A. brasilense + EM were superior to the others in accumulating dry mass at the root (39.46 grams) (Figure 4d).

At 90 DAS, when productivity was assessed, a tendency was observed for seed inoculation with A. brasilense + EM to positively affect the weight of the ears (304 grams) and the weight of the ears with straw (371.71 grams) (Figure 5a and b). This co-inoculation provided percentage gains of 25.73 percent for ear weight and 21.3 percent for ear weight with straw, compared to Control plants. However, the diameter of the ears was not significantly affected by this treatment (Figure $5 \mathrm{c})$. 
The inoculation treatments positively affected the length of the ears, with the worst averages observed in those from Control plants $(15.91 \mathrm{~cm})$ and the highest observed in ears from plants treated with EM $(18 \mathrm{~cm})$ (Figure 5d and e), with an average of 13.13 percent higher.

a)

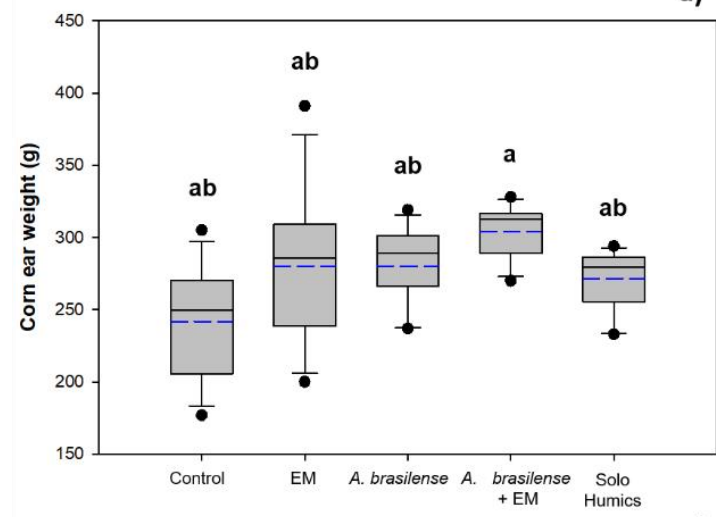

c)

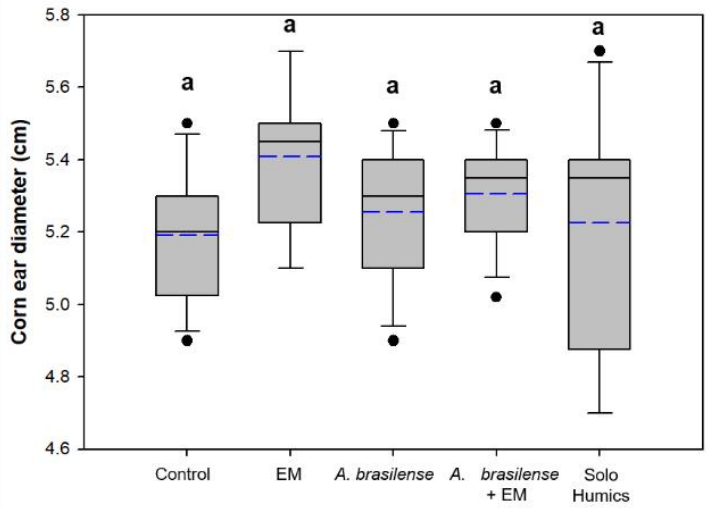

b)

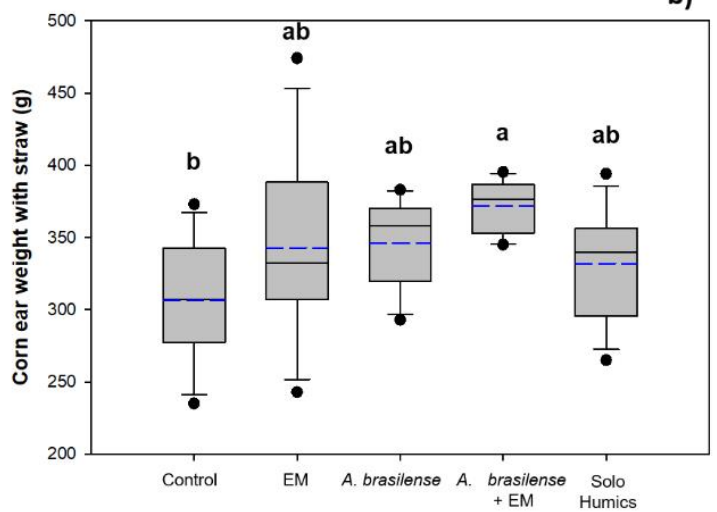

d)

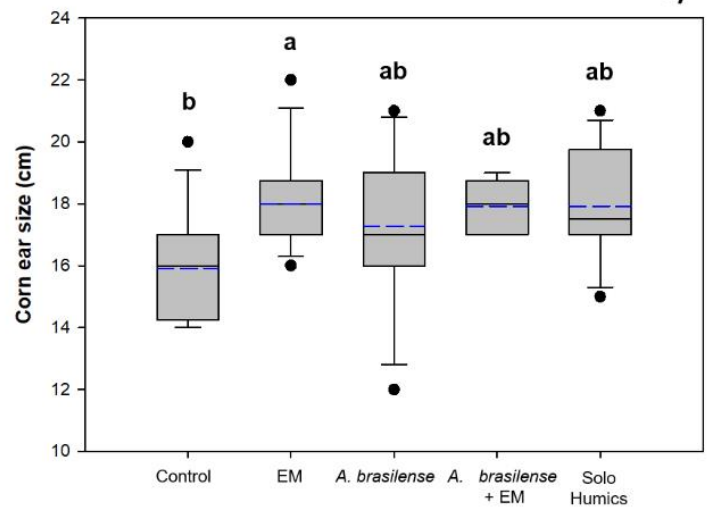

$17.27 \mathrm{~cm}$

$17.91 \mathrm{~cm}$

$17.91 \mathrm{~cm}$

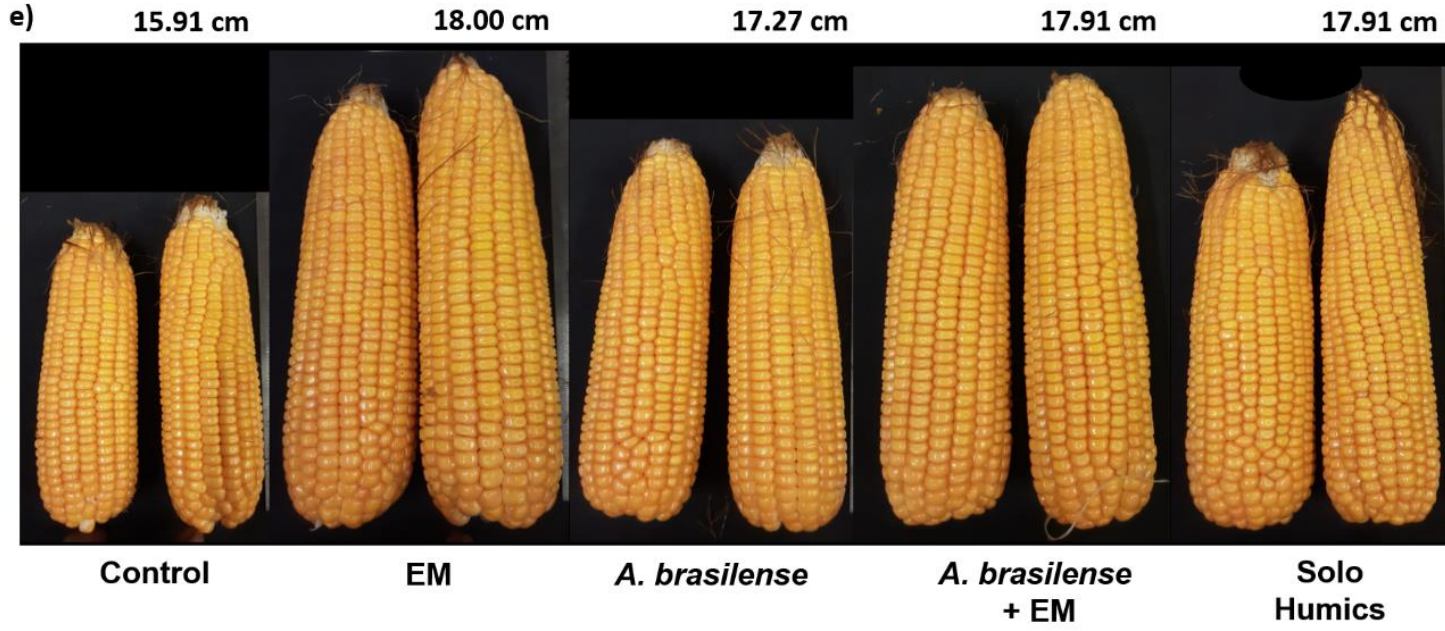

Figure 5: Corn ear weight ( $g$ ) (a), Corn ear weight with straw ( $g$ ) (b), Corn ear diameter (cm) (c), Corn ear size $(\mathrm{cm})(d)$ and Average corn ear size (cm) (e), observed at 90 days after sowing (DAS) for plants submitted to treatment with effective microorganisms (EM), A. brasilense, A. brasilense + EM, humic acids (Solo Humics) and Control. In the boxplot, the black line represents the median, the blue line the average and points observed outside are outliers. Above the boxplots, means followed by the same letter do not differ significantly by Tukey's test at 5\% probability. 


\section{DISCUSSION}

\subsection{The biopriming of corn seeds with $A$. brasilense + EM positively affected plant growth}

As expected, the co-inoculation of corn seeds with A. brasilense + EM positively affected plant height and stem diameter. This is because mixed inoculations are made up of a range of microorganisms with different functional traits, which can have multiple effects on plant growth and productivity [30]. The synergistic action of microorganisms has been explored in several studies that have evaluated since the synergistic action of mycorrhizal fungi with bacteria that promote plant growth [31], to the joint action of specific microbial strains associated with effective microorganisms [9]. Therefore, the enrichment of the inoculant of A. brasilense with EM potentiated the effect of diazotrophic in promoting plant growth.

Similarly, the treatment of seeds with Solo humics also positively affected plant height and diameter at 30 DAS. In general, humic acids can modify the dynamics of ammoniacal N, promoting an increase in the availability of $\mathrm{NH}_{4}{ }^{+}$and reduction of $\mathrm{NH}_{3}{ }^{-}$and, consequently, reduce the processes of volatilization and leaching of $\mathrm{N}$, favoring the use by cultures [32]. Therefore, at this early stage of development, a better absorption of $\mathrm{N}$ induced by these acids culminated in plant growth promotion. Similar results were observed by Baldotto and Baldotto (2016) [33] in corn plants at the early stage of development. However, in the later stages of development (60 and 90 DAS), these acids lost their effectiveness in relation to inoculation treatments, with regard to accumulation of fresh mass, dry mass, and productivity. Batista et al. (2018) [34] also found that, at $137 \mathrm{DAS}$, the use of humic/fulvic acids does not affect morphological characteristics or components of corn yield and productivity.

At 90 DAS, the co-inoculation A. brasilense + EM positively affected the accumulation of fresh and dry mass in the aerial part and root. The effects of A. brasilense on growth may be associated with its diazotrophic character for corn $[35,36]$ and also due to its ability to synthesize phytohormones as indole-3-acetic acid (IAA) [37,38], gibberellins [39] and cytokinins [40], which likely also contributed to the higher average height and stem diameter observed at 30 DAS. These effects were intensified by the synergistic action of the microorganisms that make up EM.

EM can contain anaerobic, aerobic microorganisms, as well as dozens of microorganisms with different ecological functions (lactic acid-producing bacteria, yeasts, photosynthetic bacteria, fungi and actinomycetes) $[26,41]$. This diversity of functions can be added to the effect of rhizobacteria, such as A. brasilense and enhance plant growth. Sharma and Kumawat (2012) [42] demonstrated that the inoculation of EM preparations can culminate in greater BNF in the soybean culture. These mixed cultures of natural organisms can be used as inoculants in a safe manner without risk of environmental impacts [9].

\subsection{The biopriming of corn seeds with $A$. brasilens + + EM positively affected the weight of the ears}

The positive effects of $A$. brasilense + EM co-inoculation on growth also culminated in a greater weight of corn ears. Megali et al. (2015) [43] demonstrated that the administration of effective microorganisms can not only increase corn productivity, but also reduce the diversity of insect pests that attack plants. Currently, most research evaluates the individual effect of using A. brasilense [44, 45, 46] or EM on maize crops. In research carried out by Galindo et al. (2019) [47], inoculation with $A$. brasilense increased the leaf chlorophyll index, stem diameter, ear length, and the efficiency of $\mathrm{N}$ use, with a positive effect on the yield and operating profit of the corn grain. Alternatively, Teixeira et al. (2017) [16] found that high doses of EM provided up to a 38 percent increase in plant height, 144 percent in fresh mass of aerial part, 71 percent in root length, 199 percent in fresh mass of root, 23 percent in ear mass with seeds, 20 percent in weight of grains, and 16 grain in weight of 1,000 grains.

Research involving the evaluation of the joint action of $A$. brasilense + EM in the green corn crop has not yet been published. Ribeiro et al. (2020) [8] tested the triple co-inoculation of $B$. japonicum + A. brasilense $+\mathrm{EM}$ in soybeans and found promising effects on the growth and 
productivity of the Brasmax Desafio RR cultivar. This work confirmed the hypothesis that the coinoculation of $A$. brasilense with EM can positively affect the growth and productivity of green corn, demonstrating that the enrichment of inoculants based on this diazotrophic, which aims to increase production essentially through BNF, while EM can make the treatment more effective, constituting an alternative not only to guarantee higher yields, but also to reduce the expenses with biological inputs applied to the corn crop as small producers could easily produce part of their own inoculant.

\section{CONCLUSIONS}

The co-inoculation of A. brasilense + EM is efficient in promoting the growth and productivity of green corn. Despite the treatment of seeds with humic acids having promising effects in the early stages of corn development, the effect of these acids became less satisfactory than microbial inoculation in the final evaluation phase. The biopriming of corn seeds with A. brasilense + EM is a viable technique to ensure greater productivity and sustainability of the corn crop as it is a low cost and low complexity technology.

\section{ACKNOWLEDGMENT}

The authors thank Mr. Guderio Jacinto for providing the location and resources for carrying out the experiment and the Instituto Federal Goiano (IFGoiano), for the infrastructure and the students involved in this study.

\section{REFERENCES}

1. Vitorino LC, Da Silva FO, Cruvinel BG, Bessa LA, Rosa M, Souchie EL, Silva FG. Biocontrol potential of Sclerotinia sclerotiorum and physiological changes in soybean in response to Butia archeri palm rhizobacteria. Plants. 2020 Jan;9(1):64-86, doi: 10.3390/plants9010064.

2. Vitorino LC, Palharini KMZ, Rocha AFS, Prates LS, Goulart LG, Silva AL, Bessa L. Application of bacteria symbiotic with Butia archeri (Arecaceae) to the biocontrol of the phytopathogenic fungi that deteriorate seeds of Glycine max. Seed Sci Technol. 2019 Dec;47(3):325-341, doi: 10.15258/sst.2019.47.3.08.

3. Da Silva CF, Vitorino LC, Soares MA, Souchie EL. Multifunctional potential of endophytic and rhizospheric microbial isolates associated with Butia purpurascens roots for promoting plant growth. Antonie Van Leeuwenhoek International Journal of General and Molecular Microbiology. 2018 Nov;111(11):2157-2174, doi: 10.1007/s10482-018-1108-7.

4. Etesami H. Nutrient dynamics for sustainable crop production. Nutrient dynamics for sustainable crop production. Springer. 2019. Chapter 8, Enhanced phosphorus fertilizer use efficiency with microorganisms; p. 215-245, doi.org/10.1007/978-981-13-8660-2_8.

5. Santos MS, Nogueira MA, Hungria M. Microbial inoculants: reviewing the past, discussing the present and previewing an outstanding future for the use of beneficial bacteria in agriculture. AMB Express. 2019 Dec;9(205):2-22, doi: 10.1186/s13568-019-0932-0.

6. Bulegon LG, Guimarães VF, Klein J, Batisttus AG, Inagaki AM, Offmann LC, Souza AKP. Enzymatic activity, gas exchange and production of soybean co-inoculated with Bradyrhizobium japonicum and Azospirillum brasilense. Austr J Crop Sci. 2017 Jul;11(7):888-896, doi: 10.21475/ajcs.17.11.07.pne575.

7. Ferri GC, Braccini AL, Anghinoni FBG, Pereira LC. Effects of associated co-inoculation of Bradyrhizobium japonicum with Azosprillum brasilense on soybean yield and growth. Afr J Agric Res. 2017 Jan;12(1):6-11, doi: 10.5897/AJAR2016.11711.

8. Ribeiro LDMS, Porto LS, Rocha AFS, Costa RRGF. Inoculação e coinoculação da soja com Bradyrhizobium japonicum, Azospirillum brasilense e microrganismos eficazes. Rev Mirante. 2020 Mar;13(1):66-80.

9. Himangini J, Somduttand PC, Mundra SL. Role of Effective Microorganisms (EM) in sustainable agriculture. Int J Curr Microbiol Appl Sci. 2019 May;8(3):172-181, doi: 10.20546/ijcmas.2019.803.024.

10. Lévai L, Veres Sz, Makleit P, Marozsán M, Szabó B. New trends in plant nutrition. In: Proceedings of 41st Croatian and 1st International Symposium on Agriculture; 2006 Feb 13-17; Opatija, Croácia. Opatija (HR): Faculdade de Agricultura, Universidade de Osijek. p. 39-X, 435-436. 
11. Bossuyta HS, Hendrix, JP. Protection of soil carbon by micro aggregates within earthworm casts. Soil Biol Biochem. 2005 Feb;37(2):251-258, doi: 10.1016/j.soilbio.2004.07.035.

12. Jusoh ML, Manaf LA, Latiff PA. Composting of rice straw with effective microorganisms (EM) and its influence on compost quality. Iranian J Environ Health Sci Eng. 2013 Feb;10(1):17-17, doi: 10.1186/1735-2746-10-17.

13. Postma-Blaauw MB, Bloem J, Faber JH, Van Groenigen JW, De Goede RGM, Brussaard L. Earthworm species composition affects the soil bacterial community and net nitrogen mineralization. Pedobiologia. 2006 Jul;50(3):243-256, doi: 10.1016/j.pedobi.2006.02.001.

14. Mowa E, Maass E. The effect of sulphuric acid and effective microorganisms on the seed germination of Harpagophytum procumbens (devil's claw). South Afr J Bot. 2012 Nov;83:193-199, doi:10.1016/j.sajb.2012.05.006.

15. Porto LS, Costa RRGF, Silva FV, Rocha AFS. Micro-organismos eficazes e Azospirillum brasilense: efeitos sobre a produtividade do milho. Revista de Biotecnologia \& Ciência. 2020 Set;9(2):11-21.

16. Teixeira NT, WITT L, Silva Filho PRR. Microrganismos de regeneração nas propriedades químicas do solo, desenvolvimento e produção de milho. Eng Amb: Pesq Tecnol. 2017 Jul;14(2):72-80.

17. Oliveira ALM, Santos OJAP, Marcelino PRF, Milani KML, Zuluaga MYA, Zucareli C, Gonçalves LSA. Maize Inoculation with Azospirillum brasilense Ab-V5 cells enriched with exopolysaccharides and polyhydroxybutyrate results in high productivity under low n fertilizer input. Front Microbiol. 2017 Sep;26(8):1873, doi: 10.3389/fmicb.2017.01873.

18. Portugal JR, Arf O, Peres AR, Gitti DC, Rodrigues RAF, Garcia NFS, Garé LM. Azospirillum brasilense promotes increment in corn production. Afr J Agric Res. 2016 May;11(19):1688-1698, doi: 10.5897/AJAR2015.10723.

19. Fukami J, Nogueira MA, Araujo RS, Hungria M. Accessing inoculation methods of maize and wheat with Azospirillum brasilense. AMB Express. 2016;6(1):3, doi: 10.1186/s13568-015-0171y.

20. Trevisan S, Pizzeghello D, Ruperti B, Francioso O, Sassi A, Palme K, Quaggiotti S, Nardi S. Humic substances induce lateral root formation and expression. of the early auxin-responsive IAA19 gene and DR5 synthetic element in Arabidopsis. Plant Biol. 2010 Jun;12(4):604-614, doi: 10.1111/j.14388677.2009.00248.x.

21. Mora V, Baigorri R, Bacaicoa E, Zamarreño AM, García-Mina JM. The humic acid-induced changes in the root concentration of nitric oxide, IAA and ethylene do not explain the changes in root architecture caused by humic acid in cucumber. Environm Exp Bot. 2012 Feb;76:24-32, doi: 10.1016/j.envexpbot.2011.10.001.

22. Baldotto MA, Baldotto LEB. Ácidos húmicos. Rev Ceres. 2014 Dec;61(Supl):856-881, doi: 10.1590/0034-737x201461000011.

23. Silva AC, Canellas LP, Olivares FL, Dobbss LB, Aguiar NO, Frade DOR, Rezende CE, Peres LEP. Promoção do crescimento radicular de plântulas de tomateiro por substâncias húmicas isoladas de turfeiras. Rev Bras Ci Solo. 2011 Jul;35(5):1609-1617, doi: 10.1590/S0100-06832011000500015.

24. Puglisi E, Pascazio S, Suciu N, Cattani I, Fait G, Spaccini R, Crecchio C, Piccolo A, Trevisan M. Rhizosphere microbial diversity as influenced by humic substance amendments and chemical composition of rhizodeposits. J Geochem Explor. 2013 Jun;129:82-94, doi: 10.1016/j.gexplo.2012.10.006.

25. EMBRAPA. Sistema Brasileiro de Classificação de Solos, 3. ed., rev. ampl. Brasília (DF): Embrapa; 2013. 353 p.

26. Bonfim FPG, Honório ICG, Reis IL, Pereira AJ, Souza DB. Caderno dos microrganismos eficientes (EM): Instruções práticas sobre uso ecológico e social do EM. Viçosa (MG): Universidade Federal de Viçosa, Departamento de Fitotecnia; 2011. 32 p.

27. Guerra FA. Microbiologia de alimentos: Métodos de contagem microbiana. In: Métodos de contagem microbiana [Internet]. [place unknown]: Valença; 2016. 28 p. Available from: http://ww1.microbiologiade-alimentos.com/

28. Moreira JN, Silva PSL, Silva KMB, Dombroski JLD, Castro RS. Effect of detasseling on baby corn, green ear and grain yield of two maize hybrids. Hort Bras. 2010 Dec;28(4):406-411, doi: 10.1590/S010205362010000400005.

29. R Core Team R: A language and environment for statistical computing. Vienna (AT): R Foundation for Statistical Computing; 2019. Available from: https://www.R-project.org/.

30. Adesemoye AO, Torbert HA, Kloepper JW. Plant growth-promoting rhizobacteria allow reduced application rates of chemical fertilizers. Microb Ecol. 2009 Jun;58(4):921-929, doi: 10.1007/s00248-0099531-y.

31. Emmanuel OC, Babalola OO. Productivity and quality of horticultural crops through co-inoculation of arbuscular mycorrhizal fungi and plant growth promoting bacteria. Microbiol Res. 2020 Oct;239:126569, doi: 10.1016/j.micres.2020.126569. 
32. Caron VC, Graças JP, Castro PRC. Condicionadores do solo: ácidos húmicos e fúlvicos. Piracicaba (SP): ESALQ - Divisão de Biblioteca; 2015. 46 p.

33. Baldotto MA, Baldotto LEB. Initial performance of corn in response to treatment of seeds with humic acids isolated from bokashi. Rev Ceres. 2016 Feb;63(1):62-67, doi: 10.1590/0034-737X201663010009.

34. Batista VV, Adami PF, Ferreira ML, Giacomel CL, Silva JS, Oligini KF. Ácidos húmicos/fúlvicos e nitrogênio na produtividade da cultura do milho. Braz J Biosyst Eng. 2018 Sep;12(3):257-267, doi: 10.18011/bioeng2018v12n3p257-267.

35. Da Fonseca BFA, Da Silva TFR, Dos Santos SG, Alves GC, Reis VM. Modulation of nitrogen metabolism of maize plants inoculated with Azospirillum brasilense and Herbaspirillum seropedicae. Arch Microbiol. 2019 Nov;201(4):547-558, doi: 10.1007/s00203-018-1594-z.

36. Alves GC, Sobral LF, Reis VM. Grain yield of maize inoculated with diazotrophic bacteria with the applicationof nitrogen fertilizer. Rev Caatinga [online]. 2020 Sep;33(3):644-652, doi: 10.1590/198321252020v33n307rc.

37. Molina R, Rivera D, Mora V, Lopez G, Rosas S, Spaepen S, Vanderleyden J, Cassan F. Regulation of IAA biosynthesis in Azospirillum brasilense under environmental stress conditions. Curr Microbiol. 2018 Oct;75(10):1408-1418, doi: 10.1007/s00284-018-1537-6

38. Rivera D, Mora V, Lopez G, Rosas S, Spaepen S, Vanderleyden J, Cassan F. New insights into indole-3acetic acid metabolism in Azospirillum brasilense. J Appl Microbiol. 2018 Ago;125(6):1774-1785, doi: 10.1111/jam.14080.

39. Cohen AC, Travaglia CN, Bottini R, Piccoli PN. Participation of abscisic acid and gibberellins produced by endophytic Azospirillum in the alleviation of drought effects in maize. Botany. 2009 May;87(5):455462, doi: 10.1139/b09-023.

40. Abbasi K, Mir-Mahmoodi T, Jalilnezhad N. Effects of Azospirillum bacteria and cytokinin hormone on morphology, yield and yield components of corn (Zea mays L.). Int J Biol Sci. 2015 Feb;6(3):378-386, doi: 10.12692/ijb/6.3.378-386.

41. Vicentini LS, Carvalho K, Richter AS. Utilização de microorganismos eficazes no preparo da compostagem. Rev Bras Agroecol. 2009 Dec;4(2):3367-3370.

42. Sharma MK, Kumawat D. Indigenous Effective Microorganisms (IEMs) for nitrogen fixation in JS-7322 cultivar of soybean. Earth J. 2012 Sep;2:19-26.

43. Megali L, Schlau B, Rasmann S. Soil inoculation increases corn yield and insect attack. Agron Sustain. 2015 Jul;35:1511-1519, doi: 10.1007/s13593-015-0323-0.

44. Souza E, Galindo F, Teixeira Filho M, Silva P, Santos A, Fernandes G. Does the nitrogen application associated with Azospirillum brasilense inoculation influence corn nutrition and yield? Rev Bras Eng Agr Amb. 2019 Jan;23(1):53-59, doi 10.1590/1807-1929/agriambi.v23n1p53-59.

45. Zeffa, DM, Perini LJ, Silva MB, De Sousa NV, Scapim CA, Oliveira ALM, et al. Azospirillum brasilense promotes increases in growth and nitrogen use efficiency of maize genotypes. PloS One. 2019 Abr; 14(4):e0215332, doi: 10.1371/journal.pone.0215332.

46. De Morais TP, De Brito CH, Brandão AM, Rezende WS. Inoculation of maize with Azospirillum brasilense in the seed furrow. Rev Ci Agron. 2016 Jun;47(2):290-298, doi: 10.5935/18066690.20160034.

47. Galindo FS, Teixeira Filho MCM, Buzetti S, Pagliari PH, Santini JMK. Maize yield response to nitrogen rates and sources associated with Azospirillum brasilense. Agron J. 2019 Jul;111(4):1985-1997, doi: 10.2134/agronj2018.07.0481. 